\title{
COMMENTS
}

\section{SELF-SUFFICIENCY UNDER THE EDUCATION FOR ALL HANDICAPPED CHILDREN ACT: A SUGGESTED JUDICIAL APPROACH}

There are approximately eight million handicapped Americans under the age of twenty-one. ${ }^{1}$ The Education for All Handicapped Children Act of $1975^{2}$ (the Act) is the most comprehensive legislation to date aimed at providing federal assistance to the states in their attempt to furnish handicapped children ${ }^{3}$ with a "free appropriate public education." " Because the Act fails to define explicitly the parameters of the "full educational opportunity" it calls for, 5 however, courts have faced difficulty when called upon to decide whether the content of an mdividual child's educational program is sufficient to bring the local or state educational agency imto compliance with the Act. ${ }^{6}$

1. Office of Education, U.S. Dept. of Health, Education, and Welfare, Progress Toward a Free Appropriate Public Education: A Report to Congress on the IMPLEMENTATION of PUblic Law 94-142: The Education for All HaNdicapped ChlldRen ACt 16 (1979).

2. 20 U.S.C. $\S \S 1401-1420$ (1976).

3. The Act defines "handicapped children" broadly enough to bring within its purview children afflicted with virtually any physical, mental, or emotional problem requiring special education and related services. Id. \& 1401(1). See also Lora v. Board of Educ., 456 F. Supp. 1211, 1226 (E.D.N.Y. 1978), vacated, 623 F.2d 248 (2d Cir. 1980); 45 C.F.R. § 121 a.5 (1979).

4. A state receiving funds under the Act must provide "a free appropriate public education" to all handicapped children within the state between the ages of three and twenty-one. 20 U.S.C. $\$ 1412(2)$ (B) (1976). For a brief discussion of the history of federal legislation in this field, see note 67 infra.

5. 20 U.S.C. $\S 1412(2)(A)(i)$ (1976). Although the Act explicitly details the procedures states must follow in qualifying for federal funds and in arriving at educational placement decisions for individual children, the Act's substantive provisions are drafted in broad and inclusive language. See notes 30-35 infra and accompanying text.

6. The most striking example is Armstrong v. Kline, 476 F. Supp. 583 (E.D. Pa. 1979), modified sub nom. Battle v. Pennsylvania, 629 F.2d 269 (3d Cir. 1980), cert. denied, 49 U.S.L.W. 3949 (U.S. June 22, 1981) (No. 80-827). See text accompanying notes 37-46 infra. See also Rowley v. Board of Educ., 483 F. Supp. 528, 533 (S.D.N.Y.), affd, 632 F.2d 945 (2d Cir.), appeal pending, 49 U.S.L.W. 3495 (U.S. Dec. 15, 1980) (No. 80-1002); Keuny, Education of All the Handicapped, 12 URB. LAw. 505, 508 (1980). Courts lave frequently looked to the Reliabilitation Act of 1973, 29 U.S.C. \& 794 (1976), for guidance. See, e.g., Boxall v. Sequoia Umion High School Dist., 464 F. Supp. 1104 (N.D. Cal. 1979); Howard S. v. Friendswood Independent School Dist., 454 F. Supp. 634 (S.D. Tex. 1978). 
Most cases arise under the Act when the parents of a handicapped child sue a local or state educational agency, charging that the agency has violated the Act's procedural guarantees or has failed to provide the child with a particular service allegedly required by the Act. ${ }^{7}$ The fundamental conflict among the courts is whether the Act requires that educational programs include, at a minimum, all educational services necessary to inake handicapped children self-sufficient, or whether the Act can be satisfied by educational programs aimed at a lesser goal. ${ }^{8}$ An authoritative pronouncement of the extent to which programs under the Act must be aimed at self-sufficiency is necessary to resolve the dilemma.9

Until such a pronounceinent, however, courts will continue to face the difficult task of construing the Act. ${ }^{10}$ This comment addresses that task. ${ }^{11}$ After outlining the structure of the Act in Part $1,{ }^{12}$ the comment focuses im Part II on the Act's legislative history to show that the Act was imtended to reconcile the need to protect the rights of handicapped children with the need to preserve the local nature of education. ${ }^{13}$ The comment argues that the Act requires a state to provide, at a minimum, those services necessary to enable the child to achieve the maximum

7. The analysis in this comment will be from the perspective of the handicapped children because the majority of litigation under the Act is initiated on their behalf. The poimts for consideration are equally applicable, however, when a school or state is the plaintiff. See, e.g. , Lawrence T. v. Juhia T., 103 Misc. 2d 1075, 427 N.Y.S.2d 561 (Fann. Ct. 1980) (the Commissioner of Social Services sued the parents of a handicapped child, seeking reinibursement for expenses incurred in supporting the child).

8. Sce notes 36-46 infra and accompanying text. Whether termed self-sufficiency, maximum indepeudence, or by some other label, the concept of self-sufficiency denotes the status of being able to provide for the basic needs of one's own life so as to minimize one's need for societal support. Authorities in the field of education agree that self-sufficiency is the proper goal of education in general, and of reliabilitative education in particular. See I. DICKMAN, INDEPENDENT Living: New Goal for Disabled Persons (1975); M. Jacques, Rehabilitation CounselING: SCOPE ANd Services 4 (1970); F. PAULSEN, A System of Ethics 641 (1899).

9. See notes $45-46$ infra and accompanying text.

10. Even after the substantive requirements of the Act are legislatively stated, courts inust continue to decide whether an individual child's educational prograin meets those standards. The considerations in this decision are discussed at notes 113-58 infra and accompanying text.

11. This comment does not make a detailed examination of the history of the right to education for handicapped children, or of the broader constitutional issues involved in the right to education generally. Neither does this comment address issues arising from the procedural requirements of the Act. The history of the right to education for the liandicapped is discussed in Blakely, Judicial and Legislative Attitudes Toward the Right to an Equal Education for the Handicapped, 40 Oнго ST. L.J. 603, 606-13 (1979). The possibility of a constitutional right to education is raised in Comment, The Right to Education for Mentally Retarded Children, 43 U. Mo. KaN. CrTY L. REv. 79, 80-82 (1974). For a discussion of the procedural issues arising under the Act, see Note, The Education of All Handicapped Children Act of 1975, 10 U. MrCH. J.L. REF. 110, 136-51 (1976).

12. See notes 16-29 infra and accompanying text.

13. See notes 30-112 infra and accoinpanying text. 
level of self-sufficiency that is reasonable in his case; it then suggests an appropriate standard of review. Part III of the comment discusses the proper judicial considerations for determining whether a child's educational program must include a particular educational service alleged to be necessary to achieve inaximum self-sufficiency in the specific case. ${ }^{14}$ The comment concludes that Congress or the Department of Education should clearly state that educational programs administered under the Act inust imclude, at a minimum, every service reasonably aimed at making the individual child self-sufficient. ${ }^{15}$

\section{The Structure of THE ACT}

The Education for All Handicapped Children Act of $1975^{16}$ is primarily a funding vehicle to assist the states in providing education for handicapped children. ${ }^{17}$ To receive federal funds, states must meet the requirements of the Act, the most explicit of which are procedural. ${ }^{18}$ For example, a recipient state's plan for educating handicapped children inust be approved by the Secretary of Education. ${ }^{19}$ In addition, the state inust deinonstrate to the Secretary that it "has in effect a policy that assures all handicapped children the right to a free appropriate public education."20 The state is required to describe in detail the policies and procedures it undertakes to assure that right. ${ }^{21}$ It must also establish priorities for the education of handicapped children, ${ }^{22}$ and inust ensure that local educational agencies will impleinent the mdividualized education programs mandated by the Act. ${ }^{23}$ Finally, the state must deinonstrate that its evaluation and placement procedures are not racially or culturally discriminatory. ${ }^{24}$

14. See notes 113-58 infra and accompanying text.

15. See notes 159-62 infra and accompanying text.

16. 20 U.S.C. $\$ \S 1401-1420$ (1976).

17. The Act's statement of purpose declares that "it is in the national interest that the Federal Government assist State and local efforts to provide programs to meet the educational needs of handicapped children . . . Pub. L. No. 94-142, \& 3(a), 89 Stat. 775 (1975). See Loughran v. Flanders, 470 F. Supp. 110, 113 (D. Conn. 1979) ("The chief function of the Act is to serve as a funding vehiele for the states in their efforts to provide educational opportunities for the handicapped"). See also New York State Ass'n for Retarded Children, Inc. v. Carey, 466 F. Supp. 487, 503 (E.D.N.Y. 1979). For a brief description of how funding for a state is determined, see note 81 infra.

18. See 20 U.S.C. § 1412 (1976).

19. Id. § 1413. See 20 U.S.C.A. \& 3441(a) (West Supp. 1980) (transferring responsibility for administering the Act from the Commissiouer of Education to the Secretary of Education).

20. 20 U.S.C. \& 1412(1) (1976).

21. Id. \&1412(2).

22. Id. \& 1412(3).

23. Id. \& 1412(4).

24. $I d . \S 1412(5)$. 
Decisions concerning a particular child's education are made on the basis of an individualized education program - a written prograin developed at a meeting of educators, the child, and his parents, detailing the child's present educational performance level, his appropriate educational objectives and means to achieve those objectives, and proper criteria for evaluating the child's progress. ${ }^{25}$ The Act calls for annual review and revision of the individualized program ${ }^{26}$ and specifies procedural safeguards designed to inaximize parental involvement in the placeinent decision. A child's parents or guardian, for example, must be given notice and an opportunity to present complaints whenever the local agency changes or refuses to change its evaluation of the child. ${ }^{27}$ If the guardian or parents make a complaint, they are entitled to an impartial hearing before a hearing examiner or the state educational agency. ${ }^{28}$ Any aggrieved party may appeal from the examiner to the state agency, and froin the state agency to a state or federal court. ${ }^{29}$

\section{INTERPRETING tHe SUbSTANTIVE REQUIREMENTS OF THE ACT}

\section{A. The Substantive Vagueness of the Act.}

The substantive requirements imposed by the Act are few, and they are broadly stated. In addition to mandating a "free appropriate education," 30 the Act requires states to estabhish "a goal of providing full educational opportunity to all handicapped children." 31 The most explicit substantive requireinent is that handicapped children be educated with nonhandicapped children "to the maximum extent appropriaie." 32 This requirement, known as mamstreaming, was included in

25. Id. § 1401(19).

26. Id. \& 1414(a)(5).

27. $I d . \S 1415(\mathrm{~b})(1)(\mathrm{C})$.

28. $I d . \S 1415(\mathrm{~b})(2)$.

29. $I d . \S 1415(\mathrm{e})(2)$.

30. Id. § 1412(2)(B). The Act defines a "free appropriate education" as "special education" and related services that

(A) have been provided at public expense, under public supervision and direction, and without charge, (B) meet the standards of the State educational agency, (C) include an appropriate prescliool, elementary, or secondary scliool education in the State involved, and (D) are provided in conformity with the individualized education program required under section 1414(a)(5) of this title.

Id. § 1401(18); see 45 C.F.R. § 121 a.4 (1979). "Special education" is defined as "specially designed instruction, at no cost to parents or guardians, to meet the unique needs of a liandicapped child, including classroom instruction, instruction in physical education, hoine instruction, and instruction in hospitals and institutions." 20 U.S.C. \& 1401(16) (1976); see 45 C.F.R. $\S 121 a .14(a)(1)$ (1979). "Related services" are those that "may be required to assist a handicapped child to benefit froin special education . . ." 20 U.S.C. \$ 1401(17) (1976); see 45 C.F.R. $\S 121 \mathrm{a} .13(\mathrm{a})$ (1979).

31. 20 U.S.C. $\& 1412(2)(A)(i)(1976)$.

32. Id. § 1412(5)(B); see 45 C.F.R. \& 121a.551 (1979). 
the statutory language only after extensive debate..$^{33}$ In light of the highly individualized nature of education for the handicapped, ${ }^{34}$ and in light of the difficulty with which even so broad a provision as mainstreaming was enacted, it is not surprising that Congress did not include more detailed substantive requirements in the Act. ${ }^{35}$

The Act's substantive vagueness has produced conflict within and among courts faced with determining whether a handicapped child's program of education satisfies the Act. ${ }^{36}$ The most dramatic example is Battle v. Pennsylvania, ${ }^{37}$ in which handicapped children and their parents sued in federal district court, alleging that Pennsylvania's policy of providing no more than 180 days of school annually for any child violated the children's rights under the Act. The district court concluded that the Act entitled the plamtiffs to an education aimed at developing Inaximum self-sufficiency within the limitations of their handicaps. ${ }^{38}$ The district court then held that because the lengthy interruptions in traming occasioned by the 180-day rule caused the liandicapped children to lose the skills they had acquired, the rule ran afoul of their right to an "appropriate" education. ${ }^{39}$

The Court of Appeals for the Third Circuit affirmed, but held that the Act did not specifically require the goal of self-sufficiency: "Rather, the Act contemplates that in the first instance each state shall have the responsibility of setting individual educational goals and reasonable

33. See H.R. Rep. No. 332, 94th Cong., 1st Sess. 9 (1975). The policy of educating liandicapped children in the same teaching environment as normal children is widely accepted as a beneficial approach to the cducation of the handicapped. The main objection to the Act's requirement of mainstreaming is that government should not overly restrict educators in making the individual evaluation of whether mainstreaming is appropriate in a given case. See AMicus, April 1977, at 6 (suggesting that federal statutes should not require specific teaching strategies). But see Powers, Science and Art in Mainstream Education: Toward the Normalization of the Handlcapped Child, Amicus, June 1977, at 37.

34. See Krass, The Right to Public Education for Handicapped Children: A Primer for the New Advocate, 1976 U. IlL. L.F. 1016, 1025; Stafford, Education for the Handicapped: A Senator's Perspective, 3 VT. L. REv. 71 (1978) (Senator Stafford was one of the drafters of the Act). The many factors to be considered in determining whether a particular educational service is required in a given case are discussed at notes 113-58 infra and accompanying text.

35. The Office of Education faced similar difficulties with respect to the Act's substantive regulations. In drafting 45 C.F.R. $\$ 121$ a (1979), the Office of Education avoided specific substantive regulations because of the complexity and unsettled nature of the science of learning disabilities. See 41 Fed. Reg. 52,404-05 (1976).

36. See note 6 supra.

37. 629 F.2d 269 (3d Cir. 1980), cert. denied, 49 U.S.L.W. 3949 (U.S. June 22, 1981) (No. 80827).

38. Armstrong v. Kline, 476 F. Supp. 583, 604 (E.D. Pa. 1979), modified sub nom. Battle v. Pennsylvamia, 629 F.2d 269 (3d Cir. 1980), eert. denied, 49 U.S.L.W. 3949 (U.S. June 22, 1981) (No. 80-827).

39. 476 F. Supp. at 605. 
means to attain these goals." 40 The court concluded that the 180-day rule was invalid because it precluded the state from providing the individualized treatment required by the Act. ${ }^{41}$

Judge Sloviter concurred in the result, arguing that the Act requires self-sufficiency to be the ultimate goal but allows the states freedom in implementing that goal. ${ }^{42}$ For this reason Judge Sloviter agreed with the district court's ruling that the 180-day rule violated the children's right to a free appropriate public education. ${ }^{43}$ Judge Sloviter's conclusion was somewhat more restrictive than the district court's, however; she recognized the need to limit the children's right to that degree of self-sufficiency possible within the reasonable limits of state resources. ${ }^{44}$ Battle v. Pennsylvania thus exemplifies the conflict over the degree to which educational prograins funded under the Act must be aimed at achieving self-sufficiency.

\section{B. Congressional Intent.}

The Battle court was unanimous in calling for an authoritative determination of the goal of the Act. The majority noted that in refusing to decide whether the Act requires self-sufficiency as the goal of a handicapped child's education, it was probably only delaying a decision on the matter. ${ }^{45}$ Judge Sloviter based her opinion on her belief that "elucidation of the principal goal of the statute is essential to any interpretation of its provisions, whether they are substantive or procedural."46 An analysis of the Act's goal nust begin with an exanimation of its legislative history.

1. Possible Interpretations. One interpretation of the Act is that Congress imtended to require states to provide children with all educational services necessary to achieve self-sufficiency in every case, regardless of expense or other limitations. But the legislative history of the Act suggests that Congress did not intend to adopt such an extreme position. Congress first considered whether handicapped children have

40. 629 F.2d at 276.

41. Id.

42. Id. at 284-85 (Sloviter, J., concurring and dissenting in part).

43. Id. at 284 (Sloviter, J., concurring and dissenting in part).

44. Id. at 284, 286 (Sloviter, J., concurring and dissenting in part).

45. Id. at 281 (majority opinion).

46. Id. at 284 (Sloviter, J., concurring and dissenting in part). The need for judicial interpretation of the substantive goal of the Act is discussed in Note, Enforcing the Right to an "Appropriate" Education: The Education for All Handicapped Children Act of 1975, 92 HARv. L. REv. 1103, 1127 (1979). See also the authorities cited in note 6 supra. 
a right to an education aimed at self-sufficiency. ${ }^{47}$ Although it is not clear whether there is a constitutional right to such a thoroughgoing education, ${ }^{48}$ Congress beheved that handicapped children do have the right to soine minimuin level of education. ${ }^{49}$ While inaking frequent inention of the goal of self-sufficiency, the Act's legislative history con-

47. Cited in the Act's legislative history are the leading cases of Mills v. Board of Educ., 348 F. Supp. 866, 874-76 (D.D.C. 1972), and Pennsylvania Ass'n for Retarded Children v. Pennsylvania, 334 F. Supp. 1257 (E.D. Pa. 1971), modified, 343 F. Supp. 279, 295-97 (E.D. Pa. 1972), both of which indicate that there may be a right to a free public education. See S. REP. No. 168, 94th Cong., 1st Sess. 6-7, 22-23 (1975), reprinted in [1975] U.S. CODE CONG. \& AD. NEws 1425, 1430-31, 1446-47. These and other "right to education" cases are discussed in Haggerty \& Sacks, Education of the Handicapped: Towards a Definition of an Appropriate Education, 50 TEMP. L.Q. 961, 964-84 (1977); Handel, The Role of the Advocate in Securing the Handicapped Child's Right to an Effective Minimal Education, 36 OHIo ST. L.J. 349, 356-57 (1975); Krass, supra note 34, at 102663; Note, supra note 11 , at 113 n.20.

48. The United States Supreme Court has recognized that the purpose of education is to enable students to become self-sufficient, Wisconsin v. Yoder, 406 U.S. 205, 221 (1972); Brown v. Board of Educ., 347 U.S. 483, 493 (1954), and that education is "perhaps the most important function of state and local governments," id. Furthermore, the Court has held that states that compel attendance at public schools are "constrained to recognize a student's legitimate entitlement to a public education as a property interest which is protected by the Due Process Clause . . . " Goss v. Lopez, 419 U.S. 565, 574 (1975). The Court has also ruled, however, that thcre is no fnndaniental constitutional right to an education. See San Antomio Independent School Dist. v. Rodriguez, 411 U.S. 1, 33-35 (1973). The Supreme Court has not been faced with the equal protection and due process claims that have been made on behalf of rctarded children im several lower federal court cases, but these cases strongly suggest that, insofar as states provide normal children with education, handicapped children have a constitutional right to an education aimed at self-sufficiency. See Fialkowski v. Shapp, 405 F. Supp. 946 (E.D. Pa. 1975); Mills v. Board of Educ., 348 F. Supp. 866 (D.D.C. 1972); Pennsylvania Ass'n for Retarded Children v. Pennsylvania, 334 F. Supp. 1257, modified, 343 F. Supp. 279 (E.D. Pa. 1972). One state supreune court has explicitly held that the equal protection clause of the fourtcenth amendinent to the United States Constitution gives handicapped children the right to an education. In re G.H., 218 N.W.2d 441, 447 (N.D. 1974). See generally Krass, supro note 34, at 1046-47.

49. The Act's legislative history states that

the right to education of handicapped children is a present right, one which should be inplemented immediately . . . . Congress . . . has a responsibility to assure equal protection of the laws and thus to take action to assure that handicapped children throughout the United States have available to them appropriate educational scrvices.

S. REP. No. 168, supra note 47, at 17, reprinted in [1975] U.S. CoDE ConG. \& AD. NEws 1425, 1441. A case decided shortly after the drafting of the Act provides further support for the assertion that handicapped children have the right to a minimum education. In Fialkowski v. Shapp, 405 F. Supp. 946 (E.D. Pa. 1975), suit was brought on behalf of retarded children, claiming that the school violated the children's right to equal protection and due process by attempting to tcach them academic subjects rather than essential self-help skills such as cating, walking, and dressing. Despite the defendants' argument nnder San Antonio Independent School Dist. v. Rodriguez, 411 U.S. 1 (1973), that the plamtiffs had no claim because there is no fundamental right to an education, the district court held that the plaintiffs had raised a colorable equal protection question. 405 F. Supp. at 958. The district court considered it consistent with Rodriguez to hold that "there exists a constitutional right to a certain minimum level of education as opposed to a constitutional right to a particular level of education." Id. That the Act has been found to fall within the purview of federal civil rights statutes further indicates the fundamcntal nature of the rights the Act guarantees. See, e.g., Medley v. Ginsberg, 492 F. Supp. 1294 (S.D. W. Va. 1980) (42 U.S.C. $\S 1983$ (1976)); Cruz v. Collazo, 84 F.R.D. 307 (D.P.R. 1979) (28 U.S.C. § 1343(3) (1976)). 
sistently indicates Congress's recognition that no two handicapped children will have identical needs. 50 For this reason the legislative history calls for an "appropriate" education, a term flexible enough to provide for all children, whether or not they can be educated to self-sufficiency. ${ }^{51}$ The vagueness of the Act's substantive provisions ${ }^{52}$ indicates Congress's desire to avoid an approach that would require every imaginable service for the handicapped, but its legislative history makes plain that Congress also meant to further the national goal of self-sufficiency for handicapped Americans.53 The Act was not intended, however, to create an absolute statutory right to an education resultimg im self-sufficiency; Congress was aware that the issue was too complex to warrant such a broad and indiscriminate approach. 54

Congress's awareness of the need to preserve the local nature of education ${ }^{55}$ also indicates that the Act was not meant to impose a rigid requirement of self-sufficiency on the states. Federal involvement in education erodes the freedom of the states to make pohicy in that area, and that erosion occurs regardless of whether the federal involvement is aimed at the needs of an identifiable group or at providing federal funds for education in general.56 Authorities generally agree that states should allocate their own resources, and it is therefore within the states' prerogative to determine the nature of local education. ${ }^{57}$ A state is not required to accept federal funds under voluntary statutes like the Act, ${ }^{58}$

50. See, e.g., S. REP. No. 168, supra note 47, at 10, reprinted in [1975] U.S. CodE CoNG. \& AD. NEws 1425, 1434. See also Large, Special Problems of the Deaf Under the Education for All Handicapped Children Act of 1975, 58 WASH. U. L.Q. 213, 264 (1980).

51. See S. REP. No. 168, supra note 47.

52. See notes 30-35 supra and accompanying text.

53. Congressional debates prior to the Act's passage contain statements such as the following: Failure to provide appropriate educational services for all handicapped children results in public ageucies and taxpayers spending billions of dollars over the lifetime of these individuals to maintain them as dependents in minimally acceptable life styles. Yet, providing appropriate educational services now means that inany of these individuals will be able to become a contributing part of our society, and they will not have to depend on subsistence payments froin public funds.

121 CoNG. REC. 19,492 (1975) (remarks of Sen. Williams). See also id. 25,541 (remarks of Rep. Harkin); id. 37,416 (remarks of Sen. Williams); S. REP. No. 168, supra note 47, at 9, reprinted in [1975] U.S. CoDE CONG. \& AD. NEWS 1425, 1433.

54. See notes 34-35 supra and accompanying text.

55. See notes 62-63 infra and accompanying text.

56. Compare Griffith, The U.S. Department of Education and the Issue of Control of Education, 12 URB. LAW. 500, 502-03 (1980) (the federal government should be restricted to its traditional role of serving special needs), with Rossmiller, Full State Funding of Education, in Srx CRUCIAL Issues IN EdUCATION 12 (1972) ("Experience indicates that categorical federal aids are more likely to distort local decisions than are general federal aids").

57. See Milliken v. Bradley, 418 U.S. 717, 741-42 (1974). See generally Dam, The American Fiscal Constitution, 44 U. CHI. L. REv. 271, 304-20 (1977).

58. New Mexico is the only state that has not submitted a planned program under the Act. Levinson, The Right to a Minimally Adequate Education for Leaming Disabled Children, 12 VAL. 
but once it does, a contractual relationship arises that obligates the state to accept the conditions of the federal grant. ${ }^{59}$ When a state accepts federal funds under the Act, the provisions of the Act therefore supersede conflicting state law. ${ }^{60}$ Courts have recognized that the conditions imposed by the Act greatly restrict local and state discretion in the area of education. ${ }^{61}$

Aware of the Act's potentially destructive impact on local decision-inaking, the drafters of the Act were concerned that it reflect due regard for state and local sovereignty. ${ }^{62}$ In other education statutcs, Congress has expressed this same interest in prcserving the freedoin of action of state and local authorities. ${ }^{63}$ Congress's concern that education reinam primarily a local prerogative indicates that Congress did not intend the Act to impose on the states a rigid program inandating

U. L. REv. 253, 277 \& n.135 (1978). New Mexico's program for educating handicapped children is found in N.M. STAT. ANN. \& 22-8-21 (1978 \& Supp. 1980).

59. See Griffith, supra note 56, at 502. The voluntary nature of the Aet precludes litigants from attacking the Act under National League of Cities v. Usery, 426 U.S. 833 (1976). In that case the Supreme Court invalidated certain amendments to the Fair Labor Standards Act of 1938, ch. $676, \S 1$ 1, 52 Stat. 1060 (1938) (current version at 29 U.S.C. $\$ \$ 201-219$ (1976)). The amendments extended wage and hour provisions to cover most state and local einployees. Fair Labor Standards Amendments of 1974, Pub. L. No. 93-259, § 6, 88 Stat. 58 (1974) (rcpealed). The Court held that Congress had acted outside its authority under the commerce clause, U.S. CoNST. art. I, $\$ 8$, cl. 3, because extending wage and hour requireinents to state and local einployees "displaces state policies regarding the inanner in which [states and their political subdivisions] . . . structure delivery of those governmental services which their citizens require." 426 U.S. at 847. Using more general language, the Court stated: "There are attributes of sovereiguty attaching to every state government which may not be impaired by Congress . . . because the Constitution prohibits [Congress] froin exercising . . . authority in that inatter." Id. at 845.

Although the National League of Cities Court limited its holding to the extension of federal wage and hour provisions under the commerce power, $i d$. at $852 \mathrm{n.17}$, the Supreme Court has implied that among a state's "attributes of sovereignty" is the power to provide education. Id. at 855 (dictum). See Griffith, supra note 56, at 503. The voluntary nature of the Education for All Handicapped Children Act, however, removes the Act from the purview of National League of Cities. See Halderman v. Pennhurst State School \& Hosp., 612 F.2d 84 (3d Cir. 1979), cert. granted, 100 S. Ct. 2984 (1980). In Halderman persons confined at a school and hospital for the mentally retarded brought suit under, inter alia, the Developmentally Disabled Assistance and Bill of Rights Act, 42 U.S.C. $\$ \S 6001-6081$ (1976). That act, like the Education for All Handicapped Children Act, imposes its requirements only on those states choosing to receive funds. The Halderman court noted that any arguments the school might otherwise have made under National League of Cities were vitiated by the elective nature of the funding statute. 612 F.2d at $98-99$ \& n.21.

60. Vogel v. School Bd., 491 F. Supp. 989, 993 (W.D. Mo. 1980). Accord, In re "A" Family, 602 P.2d 157, 165-66 (Mont. 1979).

61. E.g., Doe v. Koger, 480 F. Supp. 225, 231 (N.D. Ind. 1979).

62. See S. Rep. No. 168, supra note 47, at 13, 25, reprinted in [1975] U.S. Code Cono. \& AD. News 1425, 1437, 1449. See also Battle v. Pennsylvania, 629 F.2d 269, $277-78$ (3d Cir. 1980), cert. denied, 49 U.S.L.W. 3949 (U.S. June 22, 1981) (No. 80-827). Stafford, supra note 34, at 78.

63. See 20 U.S.C. \& 1232a (1976) (forbidding federal programs from controlling the local curriculum or the school administration). See also id. \& 3403 (Supp. III 1979) (the establishnent of the Department of Education shall not increase federal authority over local education). 
that they go to all extremes to provide handicapped children with an education aimed at self-sufficiency.

Another interpretation of congressional intent is that the Act merely encourages states to educate handicapped children toward selfsufficiency. ${ }^{64}$ Under this view, the Act never requires that a child's educational program be aimed at self-sufficiency; the state complies with the Act simply by providing the handicapped child with soine educational program. The legislative history suggests, however, that Congress intended inore than simple encouragement. ${ }^{65}$ Congress was well aware that, because of the cost of caring for handicapped Americans who are dependent on society for support, the national interest is well served by making the handicapped as self-sufficient as possible. ${ }^{66}$ Congress's growing concern for the plight of the handicapped is reflected in the historical trend toward greater federal involvement in the field of education for the handicapped. ${ }^{67}$ In addition, the Act's strict procedural requirements ${ }^{68}$ indicate that Congress intended to prevent states from cutting financial corners or otherwise capriciously providing for the educational needs of individual children. These requirements suggest that Congress meant to do more than merely permit

64. This is the position taken by the majority in Battle v. Pennsylvania, 629 F.2d 269 (3d Cir. 1980), cert. denied, 49 U.S.L.W. 3949 (U.S. Jnne 22, 1981) (No. 80-827). See text accompanymg notes $37-41$ supra.

65. It is clear that, at the very least, the Act encourages the goal of self-sufficiency. See note 53 supra.

66. The report of the Senate Labor and Public Welfare Committee stated:

The long range implications ... are that public agencies and taxpayers will spend billions of dollars over the lifetimes of [handicapped Americans] to inamtain such persons as dependents and in a minimally acceptable lifestyle. With proper education services, many would be able to becoune productive citizens, contributing to society instead of being forced to remam burdens. Others, through sucli services, would increase their independence, thus reducing their dependeuce on society.

S. REP. No. 168, supra note 47, at 9, reprinted in [1975] U.S. CodE CoNG. \& AD. News 1425, 1433. See also note 53 supra.

67. Congress first addressed the problein of providimg special education for the landicapped in 1966 by addimg Title VI to the Elementary and Secondary Education Act, Pub. L. No. 89-750, 80 Stat. 1191 (1966). Title VI created the Bureau of Education for the Handicapped to serve as a research center. Congress repealed Title VI in 1970 and enacted the Elementary and Secondary Education Amendments of 1970, Pub. L. No. 91-230, 84 Stat. 121 (1970) (codified in scattered sections of 20 U.S.C.), to expand the Bureau's authority to include the power to provide grants for the study and upgrading of educational programs for the handicapped.

Further amendments were nuade in 1974 to provide greater federal control over the identification, evaluation, and education of handicapped children. See Education of the Handicapped Amendinents of 1974, Pub. L. No. 93-380, 88 Stat. 484 (1974) (codified in scattered sections of 20 U.S.C.). Fimally, the Education for All Handicapped Children Act of 1975 was passed. See Pub. L. No. 94-142, 89 Stat. 773 (1975) (codified at 20 U.S.C. $\$ \$ 1401-1420$ (1976)); S. REP. No. 168, supra note 47, at 5-6, reprinted in [1975] U.S. CODE CONG. \& AD. NEws 1425, 1429-30.

68. See notes 18-29 supra and accompanying text. 
educational programs funded under the Act to be aimed at achieving self-sufficiency.

2. A Preferred Interpretation. The most satisfactory view is that Congress, in establishing the goal of full educational opportunity, intended to require states to provide every feasible service reasonably necessary to enable the handicapped child to reach his unaximuin educational potential. Full cducational opportunity will entail different goals and therefore different services for each child, depending on the severity of his handicap.

Under this view, severely handicapped children inust receive whatever services are reasonably necessary to inove thein toward selfsufficiency, even if actual attainment of self-sufficiency is impossible. ${ }^{69}$ For these children maximuin educational achieveinent may consist of inerely learning to dress theinselves, feed themselves, and toilet themselves.70 Moderately handicapped children, too, must receive all services necessary to enable them to achieve the maximum level of selfsufficiency reasonable in each case. ${ }^{71}$ As the educational objective for these children, self-sufficiency may entail learning to buy groceries, to use public transportation, or to live in a community environment. ${ }^{72}$

Mildly handicapped children who achieve self-sufficiency still have the right to full educational opportunity. For these children the state must provide whatever additional services are necessary to enable them to reach their maximum educational potential, even if these serv-

69. Self-sufficiency does not necessarily mean the maximum self-sufficiency of which a particular child is capable. All three opinions in Battle recognized this. Battle v. Pennsylvania, 629 F.2d 269, 279 n.11 (3d Cir. 1980), cert. denied, 49 U.S.L.W. 3949 (U.S. Junc 22, 1981) (No. 80 827); id. at 283 (Van Dusen, J., concurring); $i d$. at 286 (Sloviter, J., concurring and dissenting in part). See notes 37-46 supra and accompanying text. The limitations on the statutory goal of selfsufficiency are discussed at notes 113-58 infra and accompanying text.

70. An indication of the concrete educational goals typically set for these severely handicapped children can be found in the factual background of cases litigated under the Act. See, e.g., Battle v. Pennsylvania, 629 F.2d 269, 274-75 (3d Cir. 1980) (typical goals imclude toilet training, dressing, feeding, communication, counting, making change, and identifying simple words), cert. denied, 49 U.S.L.W. 3949 (U.S. June 22, 1981) (No. 80-827); Kruelle v. Biggs, 489 F. Supp. 169, 170-71 (D. Del. 1980) (the child's educational program called for speech therapy, occupational therapy, and physical therapy), aff'd sub nom. Kruelle v. New Castle County School Dist., 642 F.2d 687 (3d Cir. 1981); Fialkowski v. Shapp, 405 F. Supp. 946, 948 (E.D. Pa. 1975) (parents of children argued that children needed to learn self-help skills such as dressing, eating, and walking).

71. See Loughran v. Flanders, 470 F. Supp. 110, 112 (D. Conn. 1979).

72. An indication of the concrete educational goals typically set for these moderately handicapped children can be found in the factual background of cases litigated under the Act. See, e.g., New York State Ass'n for Retarded Children v. Carey, 612 F.2d 644, 646 \& n.l (2d Cir. 1979) (the board of education provided programs to teach social and occupational skills enabling the moderately handicapped to function im the community and in normal occupational settings). 
ices are beyond the goal of self-sufficiency. ${ }^{73}$ These services will be aimed at minimizing the detrimental effects of the handicap. ${ }^{74}$ For example, in the case of an eleventh-grade child of normal intelligence who reads at an eighth-grade level because of a hearmg defect, the state must provide those services necessary to enable the child to read at an eleventh-grade level even though an eighth-grade reading level is enough to make the child self-sufficient. On the other hand, the state is not required to provide the handicapped child with educational services that are not provided to nonhandicapped children of comparable age or intelligence. ${ }^{75}$ Thus the state need not provide an advanced calculus course for a handicapped child who has an unusually high potential, when such a calculus course is not available to nonhandicapped children.

Because the most divisive litigation under the Act often involves children who are severely or inoderately handicapped, ${ }^{76}$ for whom the goal of self-sufficiency is all-important, that class of cases provides the primary perspective froin which this comment will analyze the criteria that determine whether a child's educational prograin fulfills the Act's requirement of full educational opportunity. ${ }^{77}$ For these children the Act sets the goal of achieving the maximuin self-sufficiency that is reasonable under the circumstances, but lets the states and local educational agencies determine the particular educational services that are necessary to achieve that goal in each individual case. ${ }^{78}$

73. See, e.g., Rowley v. Board of Educ., 483 F. Supp. 528 (S.D.N.Y. 1980) (a bright child with a hearing defect is entitled to the services of a sigu language interpreter in the classroom in order to enable the child to achieve her full potential), aff'd, 632 F.2d 945 ( $2 \mathrm{~d} \mathrm{Cir.} \mathrm{1980),} \mathrm{appeal}$ pending, 49 U.S.L.W. 3495 (U.S. Dec. 15, 1980) (No. 80-1002); Loughran v. Flanders, 470 F. Supp. 110, 112 (D. Conn. 1979) (the plaintiff alleged that an inadequate educational program prevented him from functioning at his full intellectual capacity).

74. See, e.g., Howard S. v. Friendswood Independent School Dist., 454 F. Supp. 634, 635 (S.D. Tex. 1978) (special educational services had been provided to overcome the organic brain damage and anxiety that prevented a child of nornal intelligence from achieving normal progress in school); Eberle v. Board of Pub. Educ., 444 F. Supp. 41, 42 (D. Pa. 1977) (a child of aboveaverage intelligence, afflicted with profound hearing loss, required special instruction to enable him to reach his optimal development).

75. The regulations proinulgated under the Act state that an appropriate education entails the provision of services that are "designed to meet individual educational needs of handicapped persons as adequately as the needs of nonhandicapped persons are net . . . "See 45 C.F.R. $\$ 84.33($ b) (1980). See also Rowley v. Board of Educ., 483 F. Supp. 528, 534 (S.D.N.Y. 1980), aff'd, 632 F.2d 945 (2d Cir. 1980), appeal pending, 49 U.S.L.W. 3495 (U.S. Dec. 15, 1980) (No. 801002). See note 69 supra.

76. See notes 37-46 supra and accompanying text.

77. See notes 113-58 infra and accoinpanying text. Although analyzed in this comment in terms of self-sufficiency, many of these criteria are of equal innportance when the child seeks services that go beyond self-sufficiency.

78. The language of the Act supports this interpretation. While the congressioual goal of self-sufficieucy is clear, see note 53 supra, the Act defines a child's individualized educational 


\section{Accommodating the Local Nature of Education.}

In reviewing cases arising under the Act, courts unust be aware of the coinpeting concerns of the Congress that drafted the Act. The Act's language and legislative history indicate that Congress intended to secure to handicapped children the right to an appropriate education. ${ }^{79}$ But Congress was also aware that concern for the individual child's welfare inust be balanced against the principle of preserving the local nature of education in order to prevent unnecessary judicial intrusion into state and local decisions about educational policy. ${ }^{80}$ Courts deciding cases concerning an individual child's educational prograin inust integrate these coinpeting considerations. An effective understanding of the court's relationship with the locality requires a closer look at the impact a court's ruling inay have on a state or local school district.

Because the Act does not provide for the entire cost of a handicapped child's education, ${ }^{81}$ a court's decision that a child inust be given a particular educational service may drain state and local funds ${ }^{82}$ and create an expensive need for coinpetent personnel. ${ }^{83}$ The financial bur-

program, for which the state is responsible, as including "a statemcnt of annual goals, including short-term instructional objectives." 20 U.S.C. § 1401(19)(B) (1976). See note 25 supra and accompanying text.

This approach harmonizes the two conflicting interpretations of the purpose of the Act found in Battle v. Pennsylvania, 629 F.2d 269 (3d Cir. 1980), cert. denied, 49 U.S.L.W. 3949 (U.S. June 22,1981 ) (No. 80-827). See notes $37-46$ supra and accompanying text. In that case the majority held that the Act does not set a specific goal of self-sufficiency, but rather leaves the states to set individual goals for each child. 629 F.2d at 278. Judge Sloviter, like the district court below, argued that the Act does require the ultimate goal of self-sufficiency. Id. at 284, 286-87 (Sloviter, $J$., concurring and dissenting in part).

The Battle majority suggested that a pohicy statement by the Department of Education to the effect that the Act's goal is self-sufficiency for the handicapped would be helpful. $I d$. at 281 (majority opinion). A court is more willing to construe a statute according to congressional intent when the interpretation the court approves has been adopted by the agency charged with the primary responsibility for administering the legislation, in light of its special expericnce and expertise. Los Angeles Mailers Local 9 v. NLRB, 311 F.2d 121, 124 (D.C. Cir. 1962). But see Eberle v. Board of Pub. Educ., 444 F. Supp. 41, 44 (W.D. Pa. 1977) (the intent of Congress rather than of the Secretary of Education controls the interpretation of the Act). The Act's implicit grant of broad interpretative leeway has been noted in Note, supra note 46, at 1105, 1113.

79. See notes $47-54$ supra and accompanying text.

80. The criteria that determine the extent of a child's rights under the Act are discussed at notes 113-58 infra and accompanying text. For an indication of Congress's concern for federalism, see notes 63-64 supra and accompanying text.

81. Section 1411 (a)(1) of the Act determines the aniount of funds a state receives by inultiplying the number of handicapped students the state serves by a fixed dollar aniount that is not necessarily related to the actual cost of an individual child's education. 20 U.S.C. $\$ 1411$ (a)(1) (1976). See Note, supra note 46, at 1109 \& n.43.

82. Most of the cost of local education is paid out of funds derived from state and local taxes; the federal contribution is comparatively sinall. See C. Benson, The EConomics of Public Education 87-128 (2d ed. 1968); Dam, supra note 57, at 301.

83. See Note, supra note 46 , at 1110. 
den will be even greater where the court awards damages. ${ }^{84}$ If the court's decision is seen as overtaxing the financial resources or administrative talent available to the school system, states may choose to forego federal funds rather than comply with the Act. ${ }^{85}$ A state's decision to opt out of the Act may indicate strong feelings that allocation of educational funds is a local prerogative, and may therefore suggest that the Act is being construed more restrictively than Congress intended.

On the other hand, the Act clearly requires that states make certain expenditures, and provides federal funds in order to compensate for increased local costs. ${ }^{86}$ The Act is sensitive to a state's legitimate financial concerns; "appropriate education" does not mean the best education a state could give if it had unlimited financial resources. ${ }^{87}$ Rather, "appropriate education" means that available funds inust be spent equitably so that handicapped children do not bear the brunt of a state's financial limitations. ${ }^{88}$

Imposing federal requirements on the states limits local freedom in other ways as well. Because education generally reflects local values and interests, ${ }^{89}$ a court should bear in mind that its judgment inay to some degree be viewed as second-guessing collective comınunity wisdom. .9 The importance of local control of education should encourage

84. It is not clear to what extent damages are available under the Act. Although the Act does not specifically authorize a private action for damages, the broad language of the Act and its legislative history led one court to hold that such actions are permissible. See Boxall v. Sequoia Union High School Dist., 464 F. Supp. 1104, 1112 (N.D. Cal. 1979). See also S. CoNF. ReP. No. 455, 94th Cong., 1st Sess. 50 (1975), reprinted in [1975] U.S. CoDE CoNG. \& AD. News 1480, 1503. Another court, however, has held that the Act does not countenance a private action for damages. See Loughran v. Flanders, 470 F. Supp. 110, 115 (D. Conn. 1979). The damages plamtiffs seek most frequently under the Act are for expenses incurred by parents in educating their handicapped children. See, e.g., Boxall v. Sequoia Union High School Dist., 464 F. Supp. at 1111; Stemple v. Board of Educ., 464 F. Supp. 258, 260 (D. Md. 1979), aff'd, 623 F.2d 893 (4th Cir. 1980).

When damages are sought in a federal court, the court must consider whether the eleventh amendment limits the power of the federal judiciary to award damages under the Act. See Quern v. Jordan, 440 U.S. 332 (1979); Edelman v. Jordan, 415 U.S. 651 (1974); Ex parte Young, 209 U.S. 123 (1908). This line of cases holds that although the cleventh amendment does not bar the federal courts from enjoining the unconstitutional acts of state officials, it does prevent the federal courts from ordering retroactive rehef when that relief is in effect an award of damages assessed against a state treasury.

85. See note 59 supra.

86. See note 81 supra.

87. See Battle v. Pennsylvania, 629 F.2d 269, $281-83$ (3d Cir. 1980) (Van Dusen, J., concurring), cert. denied, 49 U.S.L.W. 3949 (U.S. June 22, 1981) (No. 80-827); Note, supra note 46, at 1125-26 (suggesting an approach that defines "appropriate education" in terms of available financial resources).

88. See Mills v. Board of Educ., 348 F. Supp. 866, 876 (D.D.C. 1972).

89. See Milliken v. Bradley, 418 U.S. $717,741-42$ (1974).

90. See Dandridge v. Williams, 397 U.S. 471,487 (1970). In that case welfare recipients challenged the constitutionality of the state's method for calculating welfare payments. Though 
a court to exercise restraint in deciding cases under the Act. A court must also consider whether its ruling is likely to discourage local educational innovation ${ }^{91}$ or drive away important local personnel. ${ }^{92} \mathrm{Be}-$ cause a key aim of the Act is to encourage local imventiveness, ${ }^{93}$ a ruling that has the opposite effect would run counter to congressional intent. ${ }^{94}$ All these considerations indicate that, when possible, a court should defer to local authorities in matters relating to fiscal and educational policy. ${ }^{95}$

The administrative remedies that the Act provides are perhaps the best way to reconcile the need to inaintain local control over education with the need to protect each child's rights. ${ }^{96}$ Resolution of disputes at the administrative level mamtains local input in the decision-1naking process and provides faster remedies for the plaimtiff child. A court should therefore require use of the Act's administrative reinedies in most cases.

the state increased a family's benefits with each additional child, it ceased providing these increinents once a family reached a certain size. The Court concluded that the state was properly exercising its discretion in allocating resources and that the Constitution does not einpower a court to second-guess that allocation. The Dandridge Court applied a "rational basis" standard because the welfare rule involved neither suspect classifications nor abridgement of fundamental rights. $I d$. at 484-87. Cases brought under the Act may justify a stricter standard of review, depending on the extent to which the reviewing court finds handicapped children to be a suspect class or finds a fundamental right at stake. See Lora v. Board of Educ., 456 F. Supp. 1211, 1275-76 (E.D.N.Y. 1978) (emotionally handicapped students might be characterized as a suspect class); Fialkowski v. Shapp, 405 F. Supp. 946, $958-59$ (E.D. Pa. 1975) (retarded children might be a suspect class). But see Doe v. Koger, 480 F. Supp. 225, 230 (N.D. Ind. 1979) (the court "seriously doubts" that the handicapped are a suspect class); see notes 11, 47-49 supra and accompanying text.

91. See San Antonio Independent School Dist. v. Rodriguez, 411 U.S. 1, 42-43, 49-50 (1973).

92. No agency, teacher, or other person may be held accountable under the Act's impleinenting regulations if the child does not achieve the growth projected in the Individuahized Education Program. 45 C.F.R. $\$ 121$ a. 349 (1979). See Loughran v. Flanders, 470 F. Supp. 110 (D. Conn. 1979). In refusing to find that the Act implied a private cause of action for damagcs, the Flanders court noted that to impose liability would make local school officials hesitant to implement new educational techniques for fear of exposing themselves to hability if the innovations fail. Id. at 115. But see Howard S. v. Friendswood Independent School Dist., 454 F. Supp. 634, 638 (S.D. Tex. 1978) (the court raised the possibility of imposing personal liability upon school board members for their failure to comply with the Act's procedural requirements).

93. See Loughran v. Flanders, 470 F. Supp. 110, 115 (D. Coun. 1979); H.R. REP. No. 805, 93d Cong., 2d Sess. 54-55 (1974), reprinted in [1974] U.S. CODE CONG. \& AD. NEws 4093, 4139 (a goal of all federal special education efforts is to "initiate, expand, and improve" education for the handicapped).

94. See Loughran v. Flanders, 470 F. Supp. I10, 115 (D. Conn. 1979). See also Note, supra note 46 , at $1108-09$.

95. See Battle v. Pennsylvamia, 629 F.2d 269, $277-79$ (3d Cir. 1980), cert. denied, 49 U.S.L.W. 3949 (U.S. June 22, 198I) (No. 80-827).

96. The Act provides for administrative decision-nraking by neutral representatives of state, local, or intermediate educational units. 20 U.S.C. $\$ \S 1415(b)(2), 1415$ (c) (1976). See notes 28-29 supra and accompanying text. 
Generally, when the Act's administrative remedies are adequate to handle the plaimtiff's claim, they must be exhausted before a party can seek redress in court. ${ }^{97}$ In those cases in which exhaustion of the Act's administrative remedies cannot be required, a court may nonetheless compel the parties to proceed through administrative chaimels before seeking judicial action..$^{98}$ Under the doctrine of primary jurisdiction, ${ }^{99}$ a court properly having jurisdiction over a case may refer the matter to an administrative agency 100 when the case imvolves questions that are within the agency's special field of expertise and outside the competence of the court. ${ }^{101}$ The main purpose of the doctrine is to avoid the conflict between court and administrative agency that may arise from the court's lack of expertise in the area or imexperience with agency pohicy. ${ }^{102}$ A court may also refer a case arising under the Act to an administrative decision-maker when the trial process itself threatens the welfare of the handicapped child in a way that an administrative proceeding would not. ${ }^{103}$ By referring a case to the agency, the court achieves the twim goals of avoiding unnecessary conflict between court

97. Monahan v. Nebraska, 491 F. Supp. 1074-86 (D. Neb. 1980). Exhaustion is not required when adequate administrative remedies are not available. See Doe v. Koger, 480 F. Supp. 225, 228 (N.D. Ind. 1979); 121 CoNG. REC. 37,416 (1975) (remarks of Sen. Williams). Such a situation may occur when there is no administrative procedure available to address individual grievances, $480 \mathrm{~F}$. Supp. at 228; when the administrative procedure can address only a portion of a party's claim, id.; when the administrative procedure addresses individual complaints but cannot provide an appropriate remedy, Sherry v. New York State Educ. Dep't, 479 F. Supp. 1328, 1333-34 (W.D.N.Y. 1979); when the administrative procedure is unable to consider or redress the claims of a class, Medley v. Ginsberg, 492 F. Supp. 1294, 1309 (S.D. W. Va. 1980); and when exhaustion would be futile, id.; 121 CoNG. Rec. 37,416 (1975) (remarks of Sen. Williams). And exhaustion may not be required when administrative remedies comparable to those provided by the Act have been exhausted, Boxall v. Sequoia Umion High School Dist., 464 F. Supp. 1104, 1110-11 (N.D. Cal. 1979).

98. This method of proceeding may be proper when the court feels that although a prior administrative proceeding was imeffective or was not carried out in good faith, such a proceeding can now be used with confidence under the watchful eye of the court. See Krass, supra note 34, at 1052.

99. The doctrine originated in Texas \& Pac. Ry. v. Abilene Cotton Oil Co., 204 U.S. 426 (1907). For a general discussion of the doctrine's application, see Jaffe, Primary Jurisdiction, 77 HARV. L. REv. 1037 (1964).

100. For purposes of the present discussion, the term "administrative agency" can be considered analogous to the nonjudicial decision-makers provided for by the Act. See note 96 supra.

101. See MCl Communications Corp. v. AT\&T Co., 496 F.2d 214, 220 (3d Cir. 1974). The doctrine has been addressed in cases arisimg under the Rehabilitation Act of 1973,29 U.S.C. $§ 794$ (1976). See Sherry v. New York State Educ. Dep't, 479 F. Supp. 1328, 1333-34 (W.D.N.Y. 1979); Stubbs v. Kline, 463 F. Supp. 110, 116-17 (W.D. Pa. 1978).

102. MCI Communications Corp. v. AT\&T Co., 496 F.2d 214, 220 (3d Cir. 1974).

103. Cf. North v. District of Columbia Bd. of Educ., 471 F. Supp. 136, 140 (D.D.C. 1979) (because a neglect procceding would itself liave a "devastating impact" on the child's problem, resort must be had to placement through parents or through the board of education). 
and agency ${ }^{104}$ and conserving judicial resources. ${ }^{105}$ The difficult evidentiary questions relating to educational and fiscal policy likely to arise in cases under the Act ${ }^{106}$ further suggest the benefit of deferral to an agency, though for the most part courts are competent to resolve these questions. ${ }^{107}$ Despite these cautionary considerations, a court should not be hesitant to exercise the overseeing role Congress intended it to have. ${ }^{108}$ In failing to provide clear substantive guidelines,

104. MCI Communications Corp. v. AT\&T Co., 496 F.2d 214, 220 (3d Cir. 1974).

105. A court should refer a case to an administrative proceeding if it appears that the court's resolution of the merits would do little more than settle an internal bureaucratic dispute more properly decided at the bureaucratic level. See Kruelle v. Biggs, 489 F. Supp. 169, 173-74 (D. Del. 1980), affd sub nom. Kruelle v. New Castle County School Dist., 642 F.2d 687 (3d Cir. 1981); North v. District of Colunibia Bd. of Educ., 471 F. Snpp. 136, 141 (D.D.C. 1979).

Referral under the doctrine of primary jurisdiction is properly raised on the court's own motion. Stubbs v. Kline, 463 F. Supp. 110, 116 (W.D. Pa. 1978); see Nader v. Allegheny Airlines, Inc., 512 F.2d 527, 542 n.37 (D.C. Cir. 1975), rev'd on other grounds, 426 U.S. 290 (1976).

106. Authorities agree that courts must be cautious in assessing the substantive requirements of an individual child's education. Such an assessment involves matters of educational judgment that approacl the "perimeter of judicial competence." Battle v. Pennsylvania, 629 F.2d 269, 277 (3d Cir. 1980), cert. denied, 49 U.S.L.W. 3949 (U.S. June 22, 1981) (No. 80-827). Accord, Harris v. Campbell, 472 F. Supp. 51, 55 (E.D. Va. 1979). A court must rely on expert testimony im most cases, especially when medical and psychological evaluations are at issuc. Yet a court should be careful not to rely too heavily on expert testimony in determining the ultinate issue of whether all feasible services necessary for self-sufficiency have been provided in a particular case. For exansple, in In re "A" Family, 602 P.2d 157, 167 (Mont. 1979), the court leld that it was mappropriate for counsel for the superintendent of public instruction to request at trial the opinion of a physician about the appropriateness of the plaintiff child's placeinent, where the placement had become final and lad been approved by hearing officers at both the local level and the superintendent level. A court must also be cautious whien experts disagree about which reliabilitative services constitute the "state of the Act." See, e.g., Rowley v. Board of Educ., 483 F. Supp. 528 (S.D.N.Y. 1980), aff'd, 632 F.2d 945 (2d Cir. 1980), appeal pending, 49 U.S.L.W. 3495 (U.S. Dec. 15, 1980) (No. 80-1002). The unique financial and administrative characteristics of the individual school system may require a similarly cautious rehance on expert testimony. See Note, supra note 46 , at 1127.

107. See Rowley v. Board of Educ., 483 F. Supp. 528, 533 (S.D.N.Y. 1980), aff'd, 632 F.2d 945 (2d Cir. 1980), appeal pending, 49 U.S.L.W. 3495 (U.S. Dec. 15, 1980) (No. 80-1002). See also Handel, supra note 47 , at $370-73$.

108. Section 5(a) of the Act provides for ultimate review of a placement decision by a state or federal court, but does not specify the scope of review. See 20 U.S.C. \& 1415(e)(2) (1976). Courts generally lave made a broad review both of procedural and substantive issues. The statutory language supports the Courts' broad approach. See Note, supra note 11, at 147-48. An extensive scope of review is necessary because the Act, although giving wide authority to state and local agencies to create individual education programs, does not provide clear substantive guidelines. See notes 16-44 supra and accompanying text. The Act therefore requires readily available judicial review to ensure that states and localities, while adhering to the letter of the Act's procedural requirements, do not frustrate the Act's substantive goals. See Note, supra note 46, at 1109-10.

Special considerations of federalism coine into play when cases under the Act are brought in federal court. See note 84 supra. In Younger v. Harris, 401 U.S. 37 (1971), the Supreme Court lield that im order to avoid undue federal intrusion into state dccision-making, federal courts will not enjoin state-court criminal proceedings. See 17 C. WRIGHT, A. MILLER \& E. COOPER, FEDERAL Practice and Procedure $\$ 4251$ (1978). The Younger rationale was extended in Rizzo v. Goode, 423 U.S. 362 (1976), to forbid federal injunctions against state or local administrative 
Congress may simply have expected too much of local educational agencies; ${ }^{109}$ it is therefore sometimes necessary for courts to step in.

In rendering a decision on the inerits, a court should require the handicapped plaimtiff to make a prima facie showing that his educational program does not include all components necessary to achieve the maximum self-sufficiency reasonable in his case. The burden then shifts to the institutional defendant to show that the Act does not require the child's program to include the disputed service, because the particular service is infeasible, unreasonable, or otherwise exceeds the full educational opportunity required by the Act. ${ }^{110}$ In all cases, the Act's goal of the maximum self-sufficiency reasonable im the particular case remaims firm. Thus, even when the Act does not require that a particular service be a part of the child's educational program, the Act does require self-sufficiency to be the aim of the remaining services comprising the child's program. ${ }^{111}$ This standard of review would give complainants ready access to the courts while providing local educational authorities with ample opportunity to justify their exercise of discretion. Whether the court adopts this or some other standard of review, the court should consider the broad concern of preserving the local nature of education as it weighs the criteria that determine whether an individual child's educational program must include a particular service, and therefore whether the state or local educational agency is providing an education aimed at self-sufficiency in compliance with the Act. 12

agencies. On its face, Rizzo seems to preclude virtually any federal review of state or local educational decisions under the Act. However, the Rizzo rule has been questioned as overly broad. See, eg., The Supreme Court, 1975 Term, 90 HARv. L. REv. 56, 238-47 (1976). See also Note, Rizzo v. Goode: Federal Remedies for Police Misconduct, 62 VA. L. REv. 1259, 1277-83 (1976). In addition, Congress has explicitly given the federal courts jurisdiction over cases arising under the Act, 20 U.S.C. $\$ 1415(\mathrm{e})(2)$ (1976), and the many federal decisions under the Act suggest that Younger and Rizzo are not substantial obstacles to federal review. The most compelling arguinent, however, is that because the Younger doctrine is aimed at avoiding federal interference in state procedures, federal abstention under the Act is not usually necessary. Federal review is not available under the Act until state-level administrative action, see notes 25-29 supra and accompanying text, is coinpleted. See note 97 supra and accoinpanying text. See Medley v. Ginsberg, 492 F. Supp. 1294, 1309-10 (S.D. W. Va. 1980) (Younger abstention imapplicable because no state proceedings were pending at the time suit under the Act was initiated). But see Scruggs v. Campbell, 630 F.2d 237 (4th Cir. 1980 ) (federal abstention is proper when the party aggrieved by state agency action brought suit in a state court after the opposing party liad initiated a federal action, since 20 U.S.C. $\$ 1415(\mathrm{e})(2)$ (1976) grants a right of review to the aggrieved party).

109. See Note, supra note 46 , at 1109 .

110. See Comment, Legal Remedies for the Misclassification or Wrongful Placement of Educationally Handicapped Children, 14 CoLuM. J.L. \& Soc. PROB. 389, 422-28 (1979) (suggesting that the burden of persuasion should generally be on the school). See note 138 infra.

111. See notes 69-78 supra and accompanying text.

112. One court has suggested that, as long as the child's interests are not harmed, a court should allow the local agency leeway in placing the child as necessary to ensure continued receipt 


\section{Considerations for Determining Whether a ChILD's Educational Program Must InClude a Particular Service}

A court must consider several aspects of a situation when deciding whether the Act requires a particular educational service to be imcluded in a child's educational program. Sorne of these are unique to the particular case while others represent broader concerns present im virtually every case arising under the Act. ${ }^{13}$

\section{A. The Individual Child.}

The first determination a court must make is whether the child is in fact handicapped within the meaning of the Act. ${ }^{114}$ The Act provides no remedy for those children not considered handicapped. If the court finds that the child was handicapped at the time of the placeinent decision, it inust then decide whether the defendants knew or had reason to know of the child's handicap. ${ }^{115}$ The answer will often turn on whether the defendant has comphed with the Act's procedural requireinents ${ }^{116}$ and may affect the nature of relief appropriate to the case. ${ }^{117}$

of federal funds under the Act. See In re Juvenile Case No. 1089, 119 N.H. 64, 398 A.2d 65, 68 (1979). In that case the Act's procedural requirements would have been violated, thus jeopardizmg the school's receipt of federal funds, if either the child's foster family or the state division of welfare alone, rather than the school district, had been permitted to choose the child's educational program. For that reason, the court ordered that the school district be allowed to determine the child's placement.

113. The individualized approach urged in this comment in no way precludes class actions under the Act. Violations of the Act that are severe enough to affect an entire class of handicapped children usually involve violations of the Act's procedural, rather than substantive, provisions. For exanuple, the Battle court held that Pennsylvania's 180 -day rule violated the procedural rights of the plaimtiff class. See Battle v. Pennsylvania, 629 F.2d 269, 279-80 (3d Cir. 1980), cert. denied, 49 U.S.L.W. 3949 (U.S. June 22, 1981) (No. 80-827). See also id. at 281 (Van Dusen, J., concurring); id. at 284 (Sloviter, J., concurring and dissenting in part). See notes 36-46 supra and accompanying text. The district court found the 180-day rule to violate the substantive rights of the plaintiff class as well. See Armstrong v. Kline, 476 F. Supp. 583, 605 (E.D. Pa. 1979), modified sub nom. Battle v. Pennsylvania, 629 F.2d 269 (3d Cir. 1980), cert. denied, 49 U.S.L.W. 3949 (U.S. June 22, 1981) (No. 80-827). Other class actions have been brought under the Act. See, e.g., Lora v. Board of Educ., 456 F. Supp. 1211 (E.D.N.Y. 1978); Kruse v. Campbell, 431 F. Supp. 180 (E.D. Va.), vacated and remanded, 434 U.S. 808 (1977).

114. See note 3 supra. See generally S. REP. No. 168, supra note 47, at 10, 26, reprinted in [1975] U.S. CoDE CoNG. \& AD. News 1425, 1434, 1450 ("The Committee is deeply concerned about practices and procedures which result in classifying children as having handicapping conditions when, in fact, they do not have such conditions").

115. See Mrs. A.J. v. Special School Dist. No. 1, 478 F. Supp. 418, 431-32 (D. Minn. 1979) (the mere fact that school officials suspected that the plamtiff was handicapped is not sufficient to invoke the requirements of the Act).

116. See notes 18-29 supra and accoinpanying text.

117. Compare Howard S. v. Friendswood Independent School Dist., 454 F. Supp. 634, 636, 638 (S.D. Tex. 1978) (finding that the school district had engaged in a "calculated, deliberate effort to avoid its legal responsibility" to provide an adequate education to the plaintiff under the Reha- 
Once it is clear that the child is handicapped, the court must determine whether the child's affliction makes special educational services necessary. ${ }^{18}$ Although the Act covers a wide variety of disabilities, ${ }^{119}$ there may be cases in which the child can benefit from the educational programs under the Act only if he receives services that are outside the Act's purview. ${ }^{120}$ A court should not require a school district to provide a service if the effectiveness of that service depends upon another service that is not required by the Act and is otherwise unavailable. ${ }^{121}$ In inost cases, however, the mere fact that a child needs non-educational services does not relieve the state of its duty under the Act. ${ }^{122}$

After the court has determined that the child needs educational or therapeutic services, it must consider the degree of self-sufficiency that the child can potentially achieve. ${ }^{123}$ The greater the degree of potential

bilitation Act of 1973, 29 U.S.C. $\S 794$ (1976), and under the fifth and fourteenth amendments to the United States Constitution; suggesting that personal liability be imposed on the responsible school officials), with Harris v. Canupbell, 472 F. Supp. 51, 54 (E.D. Va. 1979) (the school district's "extensive efforts" to educate the handicapped plaintiff made the court unable to find that the school district had failed or refused to provide an appropriate education for the plaintiff).

118. See 20 U.S.C. \& 1401(1) (1976) (limiting the Act's coverage to children whose handicaps "require special education and related services"). See also North v. District of Colunibia Bd. of Educ., 471 F. Supp. 136, 140 (D.D.C. 1979) (the board of education disclaimed responsibility for providing services, on the grounds that the plaintiff's problems were non-educational); Kruelle $v$. Biggs, 489 F. Supp. 169, 173 (D. Del. 1980) (saine), affd sub nom. Kruelle v. New Castle County School Dist., 642 F.2d 687 (3d Cir. 1981).

119. See note 3 supra.

120. Such a situation may arise, for exainple, in the case of a child whose complete lack of an immune response requires him to live in a bacteriologically sterile environment. See The Bubble Boy, NEWSWEEK, June 5, 1978, at 16. While the Act should require in-home instruction for the child, it should not require the school to construct on school property a sterile "bubble house" like that in the child's honie. Nonetheless, given the courts' generally broad imterpretation of the Act, it would not be surprising for a court to decide that the school must in fact provide such a structure. $C$. Tatro v. Texas, 481 F. Supp. 1224 (N.D. Tex. 1979), vacated and remanded, 625 F.2d 557 (5th Cir. 1980) (In Tatro the district court held that the Act did not require the school district to provide catheterization for the plaintiff's child. Because of a neurogemic bladder condition, the child needed catheterization every three or four hours during the school day. On appeal, the court held that catheterization is a "supportive service" required by the Act. 625 F.2d at 562). The "related services" required by the Act include transportation and supportive services for diagnostic and evaluative purposes. See 20 U.S.C. § 1401(17) (1976). See also 45 C.F.R. \& 121 1a.13 (1979).

121. If the child's parents, however, are willing to provide the service not required by the Act, the court should be free to order the school district to provide the accompanying service.

122. See, e.g., Kruelle v. Biggs, 489 F. Supp. 169 (D. Del. 1980), affd sub nom. Kruelle v. New Castle County School Dist., 642 F.2d 687 (3d Cir. 1981); Rowley v. Board of Educ., 483 F. Supp. 528 (S.D.N.Y. 1980), aff'd, 632 F.2d 945 (2d Cir. 1980), appeal pending, 49 U.S.L.W. 3495 (U.S. Dec. 15, 1980) (No. 80-1002). North v. District of Columbia Bd. of Educ., 471 F. Supp. 126 (D.D.C. 1979); In re "A" Family, 602 P.2d 157 (Mont. 1979); Smith v. Cunberland School Comm., 415 A.2d 168 (R.I. 1980).

123. The emphasis of this comment is upon those cases in which maximum self-sufficiency satisfies the goal of full educational opportumity. Handicapped children who achieve self-sufficiency have the right to receive, as part of their full educational opportunity, whatever services are 
self-sufficiency, the more important it is that the school be required to make every reasonable effort toward that end. ${ }^{124}$ A court must be especially careful not to let the present level of the child's educational program unrealistically diminish its view of what level of self-sufficiency is possible. ${ }^{125}$

A court should also consider whether and to what extent the child is likely to suffer if his educational program does not include the disputed service. If irreparable mjury is likely, ${ }^{126}$ the particular service should be a mandatory part of the child's education. Conversely, evidence that the child can easily recoup any losses resulting from the exclusion of a particular service indicates that the court should be less quick to require the state to provide the service. ${ }^{127}$

Allegations that a handicapped child presents a disciplinary problem at the school pose an especially delicate issue. ${ }^{128}$ In such cases

necessary to enable them to reach their maximum educational potential, even if such services are beyond the goal of self-sufficiency. See notes 73-75 supra and accompanying text.

124. Both the lower court and the dissenting judge in the court of appeals in Battle recognized that the Act does not require a school to go to unreasonable extremes in providing an education aimed at self-sufficiency. Armstrong v. Kline, 476 F. Supp. 583, 604 (E.D. Pa. 1979), modified sub nom. Battle v. Pennsylvania, 629 F.2d 269, 286 (3d Cir. 1980) (Sloviter, J., concurring and dissenting in part), cert. denied, 49 U.S.L.W. 3949 (U.S. June 22, 1981) (No. 80-827). See notes 37-46 supra and accompanying text.

125. See 80 HARV. L. Rev. 898,902 (1967).

126. The existence of irreparable injury, usually involving lost developmental time for the child, is important in determining when injunctive relief is appropriate. A temporary restraining order generally requires the planitiff to show that immediate and irreparable injury will result before the defendant can be fully heard in opposition. See D. DoBbs, Remedies 108-10 (1975). This form of relief is appropriate only in a few cases, such as where an irremediably harmful change in the child's placement is imminent. See Stuart v. Nappi, 443 F. Supp. 1235, 1240 (D. Coun. 1978) (finding two injuries: exclusion from both traditional and special educational programs).

A preliminary injunction requires that the plaintiff demonstrate either (1) probable success on the merits of the claim and possible irreparable injury, or (2) sufficiently serious questions going to the merits of the claim and a balance of hardship tipped in the plaintiffs favor. Triebwasser \& Katz v. AT\&T Co., 535 F.2d 1356, 1358 (2d Cir. 1976). Preliminary mjunctions have been issued in cases arising under the Act primarily to prevent a change in a child's placement, see, e.g., Monahan v. Nebraska, 491 F. Supp. 1074 (D. Neb. 1980); Vogel v. School Bd., 491 F. Supp. 989 (W.D. Mo. 1980), or to obtain a necessary change in the placement, see, e.g., Howard S. v. Friendswood Independent School Dist., 454 F. Supp. 634 (S.D. Tex. 1978). A mandamus has been issued for the same purposes. See, e.g., In re "A" Family, 602 P.2d 157 (Mont. 1979).

127. This consideration is important in determining the nature of relief, especially when a temporary restraining order or preliminary injunction is sought. Sce, e.g., Stuart v. Nappi, 443 F. Supp. 1235 (D. Conn. 1978) (a temporary restraining order was necessary becanse an imminent change in the child's placement threatened her with irreparable harm). Monetary daunage alone is unlikely to constitute irseparable harm sufficient to justify issuance of preliminary relief. See Monahan v. Nebraska, 491 F. Supp. 1074 (D. Neb. 1980).

128. In some cases the child's disciplinary problems are symptomatic of his handicap. See Doe v. Koger, 480 F. Supp. 225, 228-29 (N.D. Ind. 1979); Howard S. v. Friendswood Independent School Dist., 454 F. Supp. 634, 635 (S.D. Tex. 1978). In other cases, the educational program itself 
school district defendants frequently claim, with some justification, that the child has been removed from a needed educational program because he threatens the safety of himself or other students and teachers, ${ }^{129}$ or disrupts classes so that the education of other children is impaired. ${ }^{130}$ The Act's implementing regulations suggest that the Act's prohibition of a change in a child's placement while a complaint proceeding is pending 131 was not ineant to "preclude a school from using its normal procedures for dealing with children who are endangering themselves or others." 132 Courts have generally held that although a school may not expel a handicapped student, ${ }^{133}$ it may suspend the child on an emergency basis ${ }^{134}$ or transfer the child to a more restrictive environment. ${ }^{135}$ The Act is satisfied by a program that imcludes fewer than all elements necessary to achieve maximum self-sufficiency if those missing elements are available only in the educational setting from which the child had to be removed.

\section{B. The School System.}

In determining the extent to which a school must provide an education aimed at maximum self-sufficiency, a court should also consider the character of the school system or state. The adequacy of a handicapped child's education can be judged to some degree by a comparison with the education given to normal children. ${ }^{136}$ If a lack of local resources results in relatively low educational goals for healthy children, then correspondingly low goals for handicapped children may be acceptable. ${ }^{137}$

may cause the disciplinary problem. See Stuart v. Nappi, 443 F. Supp. 1235, 1241 (D. Conn. 1978); Frederick v. Thomas, 408 F. Supp. 832, 835 (E.D. Pa. 1976).

129. See Sherry v. New York State Educ. Dep’t, 479 F. Supp. 1328, 1337 (W.D.N.Y. 1979).

130. See Doe v. Koger, 480 F. Supp. 225, 228 (N.D. Ind. 1979). The Act's inplementing regulations state that a child's education "would not be appropriate" when he is so disruptive that the "education of other students is significantly impaired." 45 C.F.R. \& 121 la.552 (1979) (comment). See Stuart v. Nappi, 443 F. Supp. 1235, 1243 (D. Corm. 1978).

131. 20 U.S.C. $§ 1415(\mathrm{e})(3)$ (1976).

132. 45 C.F.R. $\$ 121$ 1a.513 (1979). The comment to the regulation states that schools should be allowed to use their regular procedures for dealing with emergencies. Id.

133. See Doe v. Koger, 480 F. Supp. 225, 228 (N.D. Ind. 1979). See also Stuart v. Nappi, 443 F. Supp. 1235, 1241-42 (D. Colm. 1978).

134. See Sherry v. New York State Educ. Dep't, 479 F. Supp. 1328, 1337 (W.D.N.Y. 1979). See also Stuart v. Nappi, 443 F. Supp. 1235, 1242 (D. Corm. 1978).

135. Doe v. Koger, 480 F. Supp. 225, 228 (N.D. Ind. 1979).

136. See Battle v. Pennsylvania, 629 F.2d 269, 277 (3d Cir. 1980), cert. denied, 49 U.S.L.W. 3949 (U.S. June 22, 1981) (No. 80-827). See also Note, supra note 46, at 1125-27.

137. See Battle v. Pennsylvania, 629 F.2d 269, $277-78$ (3d Cir. 1980), cert. denied, 49 U.S.L.W. 3949 (U.S. June 22, 1981) (No. 80-827); Rowley v. Board of Educ., 483 F. Supp. 528, 534 (S.D.N.Y. 1980), aff'd, 632 F.2d 945 (2d Cir. 1980), appeal pending, 49 U.S.L.W. 3495 (U.S. Dec. 15,1980 ) (No. 80-1002); Note, supra note 46 , at 1125-27. 
The court must also weigh the financial resources of the school system or state. ${ }^{138}$ A particular educational service cannot be mandatory when the school system simply cannot afford to provide the service. ${ }^{139}$ Moreover, the level of local educational and administrative expertise may often make infeasible a particular service that is necessary to achieve maximum self-sufficiency. ${ }^{140}$ To make that service a mandatory part of the child's educational program is useless when the school lacks the professional skill and management necessary to implement that service. A school that can afford to hire the appropriate personnel, however, must do so. ${ }^{141}$

\section{Compliance with Statutory Procedure.}

The Act establishes procedures to be followed in diagnosing handicaps, designing individualized education programs, and administering the remedial provisions available to aggrieved children. ${ }^{142}$ In determining the adequacy of a child's education under the Act, a court should consider the actual procedure that the school used in designing the educational program at issue. The more questionable the school's adherence to the Act's procedural requirements was, the less likely it is that the school dealt with the child in good faith. ${ }^{143}$ The school's lack of good faith im turn detracts from the reliability of the mdividualized educational program that the school developed.144 When it is unclear whether the school knew that the child was handicapped, the school's proper use of procedure becomes especially innportant in determining

138. The financial impact of a child's educational program may also be a factor in allocating the burden of proof. See Comment, supra note 110, at 421 (suggesting placing a heavier burden of persuasion on the school district if its placement decision is more convenient in terms of cost or resources). See note 110 supra and accompanying text.

139. See notes 87-88 supra and accoinpanying text.

140. See S. REP. No. 168, supra note 47, at 33, reprinted in [1975] U.S. CODE CoNG. \& AD. NEws 1425,1457 ("The Committee is aware that there is a shortage of fully qualified personnel trained to serve all handicapped children in educational programs"); Note, supra note 46, at 1110. The history of the Act's impleinenting regulations suggests that it is appropriate for a court to consider the local availability of edncational services. As initially proposed, the regulations would have required the school district to determine a child's individualized education program "without regard to the availability of those services." 41 Fed. Reg. 56,970 (1976). The final regulation, however, deleted the reference to the availability of services. 42 C.F.R. § 12la.346(c) (1979). See Amicus, Sept. 1977, at 6.

141. See Tatro v. Texas, 625 F.2d 557 (5th Cir. 1980); Rowley v. Board of Educ., 483 F. Supp. 528 (S.D.N.Y. 1980), aff'd, 632 F.2d 945 (2d Cir. 1980), appeal pending, 49 U.S.L.W. 3495 (U.S. Dec. 15, 1980) (No. 80-1002); Sherry v. New York State Educ. Dep't, 479 F. Supp. 1328, 1339 (W.D.N.Y. 1979).

142. See notes 18-29 supra and accompanying text.

143. See note 117 supra.

144. $I d$. 
whether the school had reason to know of the handicap. ${ }^{145}$ That determination affects the degree of culpability attaching to the school's failure to diagnose the child's condition, and therefore affects the kind of relief appropriate in the case. ${ }^{146}$

An examination of the actual procedure that was used in diagnosing a child's condition and designing his educational prograin is useful in revealing whether the questioned placement decision - the diagnosis and its resultant educational prograin-was inade on non-educational grounds. As already noted, a placeinent inade for non-educational reasons such as discipline inay coinply with the Act in soine circuinstances even though the resulting educational program does not include every element necessary for inaximum self-sufficiency. ${ }^{147}$ In inost situations, however, the requirements of the Act take precedence over decisions inade on non-educational grounds. ${ }^{148}$

Finally, the court nust carefully determine whether the procedures that were followed, even if proper in form, adequately protected the interests of the child. Because the Act depends largely on parental involveinent in the decision-inaking process, ${ }^{149}$ a court should examine whether the child's parents were able to use the Act's remedial procedures effectively. ${ }^{150}$ Many parents are unable to afford a lawyer to assist in dealing with the Act's appeal process, ${ }^{151}$ and in such cases the court should give less credence to the result of the administrative appeal if it was unfavorable to the child.

\section{General Considerations.}

In deciding whetler the goal of inaximum self-sufficiency has been met in a particular case, a court may look to cases arising in similar districts or states. ${ }^{152}$ Similarities in other districts nay also guide the school system in implementing the court's decision. Rarely, if ever, will two courts be presented witl cases involving the same handicapping condition in the same educational context; courts should therefore draft their opinions narrowly to avoid creating inappropriately broad prece-

145. See Mrs. A.J. v. Special School Dist. No. 1, 478 F. Supp. 418, $431-32$ (D. Minn. 1979).

146. See note 117 supra.

147. See notes 128-35 supra and accompanying text.

148. See note 122 supra and accompanying text.

149. See notes 25-29 supra and accompanying text.

150. See Note, supra note 46 , at 1111-12.

151. Id. 1111.

152. See Kruelle v. Biggs, 489 F. Supp. 169, 173 (D. Del. 1980), affd sub nom. Kruelle v. New Castle County School Dist., 642 F.2d 687 (3d Cir. 1981). But see note 106 supra. 
dents. ${ }^{153}$

A final practical consideration relates to the unpleasant economic realities of education for the handicapped. Generally, the more severe a child's handicap, the more it costs society to care for the child over the course of his life if he is not made self-sufficient. ${ }^{154}$ By the same token, the more severe the handicap, the more it costs society to educate the child to self-sufficiency. ${ }^{155}$ Congress has determined that it is in the national interest to educate handicapped children to self-sufficiency. ${ }^{156}$ Nonetheless, a court may consider the relative costs in a given case. A particular educational service necessary to maximize self-sufficiency should not be required when the massively expensive service, althougll affordable by the school system, will leave the handicapped person's dependence on societal support relatively unchanged. Fimally, a court must recognize that the expensive education that handicapped children require does sacrifice to some extent the education available to normal children. ${ }^{157}$ A particular service necessary to maximize a handicapped child's self-sufficiency should not be mandatory when the detriment to society resulting from the lost education for normal children outweighs society's gam in providing a particular kind of education for the handicapped child. A court is not free to substitute its view for the intent of Congress expressed in the national policy goals set by the Act, ${ }^{158}$ but the considerations of relative cost and sacrificed resources are relevant criteria in extreme cases.

\section{Conclusion}

The diversity of handicapping conditions and of local educational resources, and a desire to preserve local control of education led Congress to employ flexible language in drafting the Education for All

153. See Battle v. Pennsylvania, 629 F.2d 269, 281 (3d Cir. 1980) (Van Dusen, J., concurring) (the judge concurred "to emphasize . . . the limited nature of our holding in this case"), cert. denied, 49 U.S.L.W. 3949 (U.S. June 22, 1981) (No. 80-827).

154. See S. REP. No. 168, supra note 47, at 9, reprinted in [1975] U.S. CoDE CoNG. \& AD. NEWS 1425, 1433.

155. A handicapped child is, on the average, approximately twice as expensive to educate as a normal child. See S. REP. No. 168, supra note 47, at 15, reprinted in [1975] U.S. CoDE CONG. \& AD. NEws 1425, 1439. Congress has authorized appropriations for the Act of $\$ 236.5$ million for 1981 and \$247.5 million for 1982. Education of the Handicapped Amendincnts of 1977, Pub. L. No. 95-49, §§ 2-6, 91 Stat. 230 (1977) (codified at 20 U.S.C. § 1426 (Supp. III 1979)).

156. See note 17 supra.

157. Because the Act does not pay for the entire cost of a handicapped child's education, educational programs under the Act necessarily consume state or local financial resources otherwise available for the education of normal children. See notes 81-82 supra and accompanying text.

158. IsraeI v. Motor Vessel Nili, 435 F.2d 242 (5th Cir. I970), cert. denied, 401 U.S. 994 (1971). 
Handicapped Children Act of 1975.159 The Act's legislative history reveals that Congress intended maximum self-sufficiency for the handicapped to be the mimimum goal of education under the Act, while allowing state and local governments to set increinental goals toward that end. ${ }^{160}$

In determining whether the content of a child's education satisfies the self-sufficiency requireinent and thereby brings a state into coinpliance with the Act, a court should require the state to provide every educational service necessary to enable the child to achieve the inaximum level of self-sufficiency that is reasonable in his case. ${ }^{161}$ Courts should recognize the traditionally local nature of educational pohicy formulation and should temper their concern for the child's well-being with an awareness of the need to preserve a proper relationship between the court and the commumity.

Ultimately, Congress should make a clear pohicy statement by amending the Act to require states to provide, at the least, every service reasonably necessary to maximize self-sufficiency. ${ }^{162}$ Courts can then more easily apply the Act to secure the rights of handicapped children.

John S. Harrison

159. 20 U.S.C. $\$ \S-7401-1420$ (1976).

160. See notes 69-78 supra and accompanying text. But see Battle v. Pennsylvania, 629 F.2d 269 (3d Cir. 1980), cert. denied, 49 U.S.L.W. 3949 (U.S. June 22, 1981) (No. 80-827). In light of the Act's legislative history and the unique need for flexible statutory language, the position of the inajority in Battle -that the Act does not mandate the goal of maximun self-sufficiency-is unpersuasive.

161. See note 123 supra.

162. Such a statement would simplify to some degree the courts' task. A clear expression of a nnandatory goal of maximum self-sufficiency would also lead to more faithful implementation of the Act. Such a mandate would be more difficult for a local school official to ignore than a flexible rule, especially when a violation can jeopardize the receipt of federal funds. See 20 U.S.C. § 1416 (1976). See Sherry v. New York State Educ. Dep’t, 479 F. Supp. 1328, 1334 (W.D.N.Y. 1979). In addition, parental involvement would be more effective because clear guidelines would make it more evident when a child's rights were being violated. See Note, supra note 46, at 1110 . 